\title{
Rare Case of Perianal Endometriosis Complicated with Perianal Fistula: Case Report
}

\author{
Lucian Sorin ANDREI ${ }^{1,2}$, Radu Sorin POPISTEANU ${ }^{2}$, Adriana Corina ANDREI ${ }^{1,2}$, Mona DUMBRAVA ${ }^{2}$, \\ Maria BLACIOTI
}

\begin{abstract}
Perianal endometriosis is a rare pathology which occurs mainly in patients with history of vaginal birth associated with an episiotomy scar. We present the case of a 42 year old patient with history of multiple interventions for right perianal fistula, accusing pain, purulent secretions and bleeding at the site of the interventions. Biopsies collected were specific for endometriosis. In the context of the sphincter involvement, which brings a high risk of incontinence, and the hormone-dependent evolution of this pathology, which tends to regress once menopause is reached, a fistulotomy was made, with subsequent remission of the purulent secretions, but with the persistence of the bleeding from the region during the menstrual cycle.
\end{abstract}

Keywords: endometriosis perianal, fistula, fistulotomy.

\section{Rezumat}

Endometrioza perianală este o patologie rară, ce survine mai ales la paciente cu istoric de nașteri vaginale asociate cu epiziotomie. Prezentăm cazul unei paciente de 42 de ani, în antecedente cu multiple intervenții pentru fistulă perianală dreaptă, acuzând dureri și exteriorizare de secreții purulente și sangvinolente de la acel nivel. Biopsiile prelevate intraoperator susțin diagnosticul de endometrioză. În contextul afectării sfincteriene ce aduce cu sine un risc mare de incontinență, și a evolutiei hormo-dependente a acestei patologii, ce tinde să regreseze odată cu apariția menopauzei, s-a optat pentru practicarea unei fistulotomii, cu remiterea secrețiilor purulente și menținerea unei secreții sangvinolente concomitent cu ciclurile menstruale.

Cuvinte cheie: endometrioză, perianal, fistulă, fistulotomie.

\section{INTRODUCTION}

Endometriosis is a pathology defined by the presence of functional endometrial tissue ourside of the uterus. The most frequent locations are the ovaries, uterosacral ligaments, and the rectum. Perianal region is a rarely affected $^{1,2}$. It is a condition that affects between $20 \%$ and $50 \%$ of women that are infertile $e^{3}$. In one study in a specialised centre in China, between 1992 and 2011, out of a total a 17263 patients operated for endometriosis, 64 patients $(3.7 \%$ out of the total) presented endometriosis in the perianal region, and 31 (1.8\%) had sphincter involvement ${ }^{4}$.

\section{CASE PRESENTATION}

We present the case of a 42 year old patient, accusing perianal pain associated with purulent secretions and
${ }^{1}$ Mediproct Clinic, Bucharest, Romania

${ }^{2}$ Fundeni National Institute, Bucharest, Romania

\section{Corresponding author.}

Lucian Sorin ANDREI, Fundeni National Institute, 158 Fundeni Avenue, $2^{\text {nd }}$ District, Bucharest, Romania.

E-mail: sandrei741@yahoo.com 


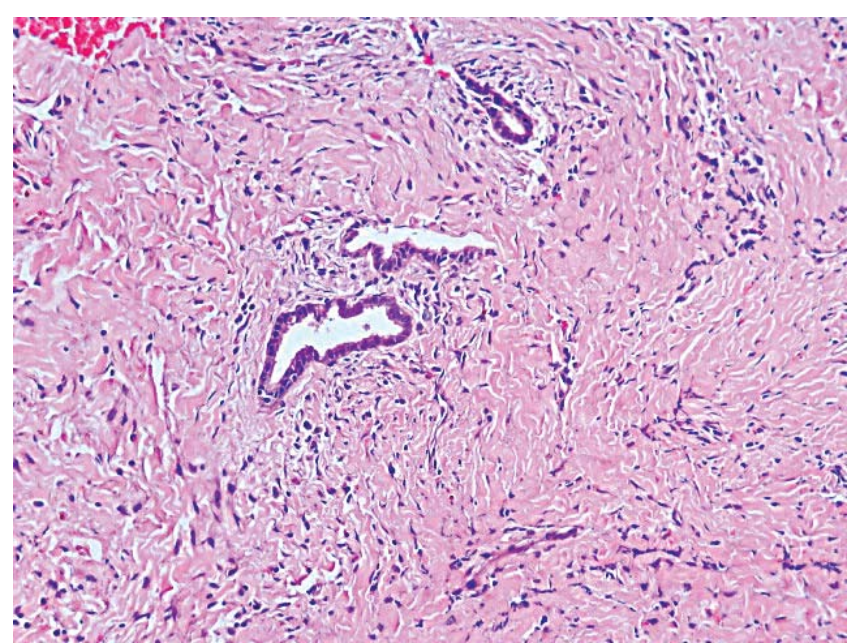

Figure 1. Focal tubular glands with a single epithelial layer, embedded in a dense connective tissue, HE stain, x200.

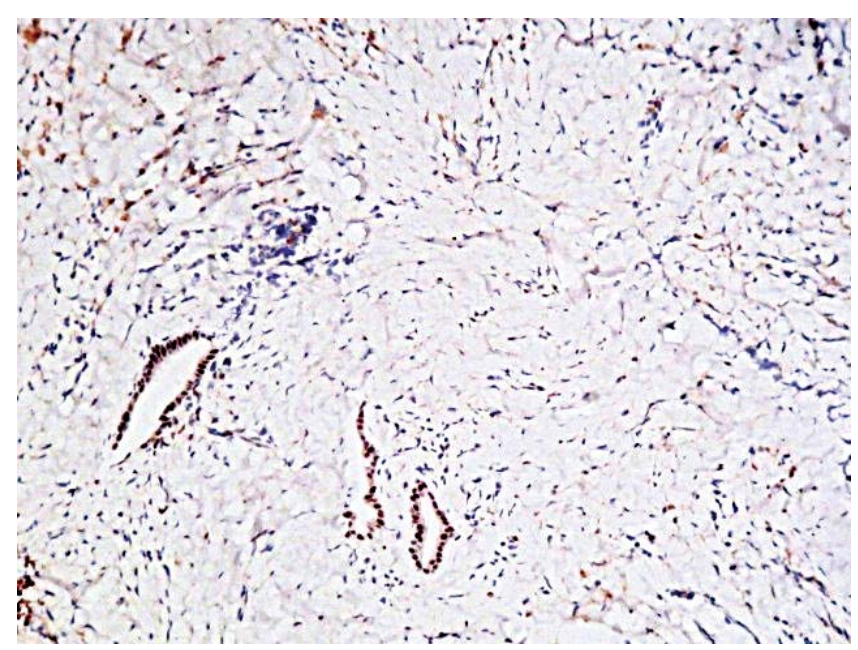

Figure 2. Positive immunohistochemistry reaction for estrogen receptors in glandular epithelium, x200.

bleeding. The patient has history of multiple interventions for perianal fistula between 2015-2018, the last operation consisting of the insertion of a drainage seton. The patient has history of vaginal birth associated with right lateral episiotomy at the age of 21 .

At the clinical examination we detect low transphincteric perianal fistula, with an applied drainage seton and multiple perianal and right ischioretal fluid collections, suggestive for "hourglass” shape abscesses. Anuscopy revealed the internal orifice of the fistula at $1 \mathrm{~cm}$ in the anal canal, at 1 o'clock in lateral left decubitus and turgescent haemorrhoids with signs of recent bleeding.

The MRI and endoanal ultrasound have detected a perianal abscess of about $3 \mathrm{~cm}$, with multiple fistulous ramifications that go deep into the adipose tissue, with surrounding fibrous scar tissue in the context of previous surgeries, which made the evaluation of sphincter involvement difficult.

As for blood tests, the patient had no inflammatory syndrome, and the tumour marker CA 125 was within normal range. There are studies that have demonstrated the superiority of this marker in detecting pelvic endometriosis ${ }^{5}$, although it is not specific for other sites of endometriosis, perianal included ${ }^{6}$.

The surgery consisted of incision, evacuation of the abscesses, fistulotomy, multiple sphincter and ischiorectal biopsies and wound dressing. Postoperative evolution is initially favourable, but in the $22^{\text {nd }}$ day, the surgical wound gained a swollen aspect and presented bleeding at the time of the menstrual cycle. Bleeding was not associated with pain. The biopsy results (hematoxylin and eosin colouring) are positive for perianal fistula, immunohistochemistry confirms the endometriosis (stroma and glands strongly express estrogen, glandular epithelium expresses CK7 and CD10 with minimal reaction). Thus the final diagnosis is perianal endometriosis complicated with low transphincteric fistula and perianal and right ischiorectal abscesses. Endocrinological and gynaecological assessment recommends hormonal inhibitor treatment with diphereline. The patient refuses both hormonal treatment and surgical castration, choosing therapeutic abstinence in the context of approaching menopause and the possibility of the regression of endometriosis.

\section{DISCUSSION}

Perianal endometriosis is a rare pathology, and in most of the cases presented in literature, the patient presented episiotomy scar from vaginal birth, incision that is the primary implantation site for endometrial tissue ${ }^{7}$. The multitude of previous surgeries that led to the persistence of local suppuration made it impossible to determine the cyclic character of the bleeding. In a study of endometriosis of the abdominal wall, abdominal pain was not associated with the menstrual cycle in $75 \%$ of cases $^{8}$. At the operating moment, in lack of the suspicion of perianal endometriosis, the choice was made to cure the fistula and to evacuate the perianal and ischiorectal abscesses, the wide curettage of the tissues that were considered fibrous at the time of the intervention, avoiding the areas where the apparent fibrous tissue involved the anal sphincter. The final diagnosis in this case came after the operation, in the results of the biopsy collected during surgery. There are studies that have demonstrated the superiority of the fistulotomy 
regarding continence impairment and healing time ${ }^{9}$. In this case the fistulotomy was completed with wide curettage of the apparent fibrous tissues, avoiding the anal sphincter. Studies have constantly shown a correlation between an episiotomy scar in patient history and perianal endometriosis. The time between the episiotomy and the appearance of the first symptoms was 18 years. The patient did not acknowledge the presence of perianal nodules before the first perianal abscess occurred, and none of the previous surgeries had collected a biopsy. The patient has chosen conservative treatment in the context of age approaching menopause, which favours natural regression of endometriosis. A case of perineal endometriosis that had spontaneously regressed after a pregnancy was reported, sustaining that fact that it is a hormone-dependent pathology ${ }^{10}$. The malignancy rate of endometriosis is cited to be low, between $0.7 \%$ $1 \%$, of which $80 \%$ occurs in the ovaries ${ }^{11}$. Postoperative follow up, for a period of 18 months, consisted of local bandaging of the wound during menstrual cycles, without local suppuration.

\section{References}

1. Schweiger W, Bacher $\mathrm{H}$, Cerwenka H, Mischinger HJ. Perianal endometriosis with involvement of the external anal sphincter. Eur J Surg. 1999;165:615-617

2. Snyder M, Stryker S. The ASCRS Textbook of Colon and Rectal Surgery. Springer 2007; 21: 308-321.

3. Rawson JM. (1991). Prevalence of endometriosis in asymptomatic women. J Reprod Med, Vol.36, (1991), pp. 513-515, ISSN 0024-7758

4. Na Chen Lan Zhu Jinghe Lang Zhufeng Liu Dawei Sun Jinhua Leng Qingbo FanHui Zhang Quancai Cui ; The clinical features and management of perineal endometriosis with anal sphincter involvement: a clinical analysis of 31 cases Hum Reprod. 2012 Jun;27(6):1624-7

5. Pittaway DE, Douglas JW Serum CA-125 in women with endometriosis and chronic pelvic pain; Fertil Steril. 1989 Jan; 51(1):68-70.

6. Diagnosis and Treatment of Perineal Endometriosis Lan Zhu, $\mathrm{Na}$ Chen and Jinghe Lang Dept. of O/G of Peking Union Medical College Hospital, Chinese Academy of Medical Science, Beijing,

\section{CONCLUSION}

There are 3 criteria on which the diagnosis of perianal endometriosis can be based: history of vaginal birth, palpable nodules of moderate consistency in the perianal region, and pain worsened during the menstrual cycle, followed by perianal bleeding ${ }^{12}$. One role in adopting an adequate therapeutic conduct is the hormone-dependent evolution of this pathology, especially when the anal sphincter is involved and there is a high risk of incontinence in the case of wide excision, which are to be avoided.

\section{Compliance with ethics requirements:}

The authors declare no conflict of interest regarding this article.

The authors declare that all the procedures and experiments of this study respect the ethical standards in the Helsinki Declaration of 1975 , as revised in 2008(5), as well as the national law. Informed consent was obtained from all the patients included in the study.

P. R. China. Published: May 9th 2012, DOI: 10.5772/1193 ISBN: 978-953-510524-4

7. Marquez J, Marquez JC, Arraztoa JA et al: Extrapelvic endometriosis involving the perineum, Rev Chil Obstet Ginecol 1995 ;60:1-4.

8. Ano Zuhair Bashir Kamal Fistulotomy Versus Fistulectomy As a Primary Treatment of Low Fistula in Ano THE IRAQI POSTGRADUATE MEDICAL JOURNAL 2012; 11:4

9. Beischer NO. Endometriosis of an episiotomy scar cured by pregnancy. Obstet Gynecol 1966; 28:15-21.

10. Heaps J.M., Nieberg R.K., Berek J.S. Malignant neoplasma arising in endometriosis. Obstet Gynecol. 1990;75:1023-1028

11. Zhu L, Lang J, Wang H, Liu Z, Sun D, Leng J, Zhou H, Cui Q, Wong F. Presentation and management of perineal endometriosis, Int J Gynaecol Obstet, 2009; 105: 230-232,

12. Jan-Hein J. Hensen1, Adriaan C. Van Breda Vriesman2 and Julien B. C. M. Puylaert1 American Journal of Roentgenology. 2006;186: 616-620. 
